\title{
Update: Biological and Chemical Aspects of Senna spectabilis
}

\author{
Denise M. Selegato, ${ }^{\#}$ Afif F. Monteiro, ${ }^{\#}$ Natália C. Vieira, ${ }^{\#}$ Patrícia Cardoso, ${ }^{\#}$ \\ Victor D. Pavani, ${ }^{\#}$ Vanderlan S. Bolzani and Ian Castro-Gamboa*
}

\author{
Núcleo de Bioensaios, Biossíntese e Ecofisiologia de Produtos Naturais (NuBBE), Instituto de \\ Química (ICAr), Universidade Estadual Paulista (UNESP), 14800-060 Araraquara-SP, Brazil
}

Senna spectabilis (syn Cassia spectabilis) is one of the most important species within the Fabaceae family, natively found in Central and South America, as well as parts of Asia and Africa. Due to the extensive geographical distribution, this fast-growing tree produces a wide variety of bioactive secondary metabolites, being of special interest for chemical and pharmacological studies. Phytochemical investigations have shown that $S$. spectabilis produces over 40 constituents from different biosynthetic pathways, including piperidine alkaloids, pentacyclic terpenoids and anthraquinones, displaying antiproliferative, antitumoral and antifungal activities. Moreover, studies have also been conducted to identify endophytic and rizhospheric microorganisms associated to $S$. spectabilis and their chemical composition, enabling further elucidation of cadinane sesquiterpenoids, cytochalasins, depsipeptides and dibenzopirones. This review aims to provide an updated summary of the main features of $S$. spectabilis, compiling all currently available information on the chemical and pharmacological composition of its parts and its associated microorganisms.

Keywords: Senna spectabilis, phytochemistry, biological activity, associated microorganisms, bioprospection

\section{General Overview on S. spectabilis}

Leguminosae, one of the largest taxonomic group in Angiospermae, has changed to Fabaceae after recent phylogenetic studies based on DNA sequences and, within this new classification, Fabaceae is divided into three subfamilies Mimosoideae, Fabaoideae and Caesalpinioideae, the latter including Cassia and Senna. ${ }^{1,2}$ However genetically divided, these genera still have complex taxonomic separation, with unclear genetic and chemical classification, including several species of Senna previously described as Cassia, while others remained as Cassia and adopted Senna as a synonym..$^{1,2}$

Senna comprises over 600 species distributed towards the tropical and subtropical regions of the world, encompassing shrubs, herbs and trees capable of reaching 4-9 meters in height. Its morphology includes rounded crown, dark green and small leaves, alternate spiral, stipulated composed paripinnate, with 10-20 pairs of leaflets oval to oblong-elliptical, rounded base, acute apex and glabrous, 2-4 cm long. ${ }^{2,3}$ Flowers are yellow, showy,

*e-mail: ian.castro@gmail.com

"These authors contributed equally to this work. arranged in terminal inflorescences, while the fruits are pod type $25-32 \mathrm{~cm}$, elongated, cylindrical, indehiscent, black, with brown seeds endowed with pleurograma., ${ }^{2,3}$

Within this taxonomic rank, Senna spectabilis (syn Cassia spectabilis) is one of the most important species, broadly studied towards their chemical and pharmacological aspects. Popularly known as Cassia, mwenu, Cássia do Nordeste, Acássia, Tula-de-Besouro, Canafístula-de-Besouro, Pau-de-Ovelha, mhomba, antsoan dilaw, scented shower and Panama-ngu, this fast growing tree is used in both eastern and western traditional medicine, treating several different diseases and symptoms. ${ }^{2,4}$ In eastern medicine, this plant is traditionally used as laxative, antimicrobial, anti-inflammatory and antiulcerogenic, while in Asiatic countries, it is also known to treat rheumatism, pain and skin lesions. . $^{2,45}$

Natively found in Central and South America, this tree is commonly found in several Brazilian biomes, mainly in the cerrado region (savanna like) and the rainforest. ${ }^{3,4,6}$ Urbanistically, S. spectabilis is used as an ornamental plant and on the recovery of degraded areas, due to its beautiful yellow flowers and global distribution., ${ }^{5,6}$

Phytochemical studies revealed that over 350 molecules were isolated from Senna, including 40 secondary 
metabolites from S. spectabilis (Table 1). Among those, piperidine alkaloids and pentacyclic triterpenes are the most common classes, exhibiting high biological activities further described on this review.

Along with biological and phytochemical researches, recent studies have also been conducted aiming to understand the chemical and ecological interactions between these species and the microorganisms that co-habit it, allowing the elucidation of important secondary metabolites, such as cytochalasins, dibenzopirones and cadinane sesquiterpenes from the endophytic fungi Phomopsis cassiae, and hexadepsipeptides from the enniatin family and picolinic acid analogues from S. spectabilis's rhizosphere associated fungi Fusarium oxysporum and $F$. solani..$^{7-9}$ All metabolites identified for $S$. spectabilis's related microorganisms are listed and can be seen on the Supplementary Information.

\section{Phytochemistry}

\section{Alkaloids}

S. spectabilis is known to possess piperidine alkaloids (1-21) as major constituents of leaves, flowers and green fruits (Figure 1). ${ }^{6}$ This cyclic nitrogen compounds show high pharmacological interest, exhibiting strong antitumor, leishmanicidal, analgesic, antimicrobial, purgative and anticonvulsant effects, as well as modulating the treatment of neurodegenerative diseases by the inhibition of superoxide, lipid peroxidation and against ciclooxigenase (COX) 1 and 2. ${ }^{10-16}$

Piperidine alkaloids were extensively studied through the years, being (-)-cassine (1) the first alkaloid discovered on leaves of $S$. spectabilis. This secondary metabolite was isolated in 1976 by Christofidis et al.,${ }^{17}$ along with two new alkaloids, (+)-spectaline (2) and (-)-iso-6-cassine (3).

Compound 1 was firstly reported from the leaves of another Fabaceae specie named Cassia excels, in 1964, and its absolute configuration was determined two years later, in $1966 .{ }^{18,19}$ Also known as $12-[(2 R, 3 R, 6 S)$-3-hydroxy2-methylpiperidinyl]-6-dodecanone, this alkaloid shows interesting antinoceptive, anti-inflammatory, leishmanicidal and cytotoxic, ${ }^{11,20}$ while (-)-iso-6-cassine (12-[(2R,3R,6R)3-hydroxy-2-methylpiperidinyl]-6-dodecanone) presents CNS depressant and anticonvulsant activities. ${ }^{16}$

In 1977, Christofidis et al..$^{21}$ isolated two new alkaloids from the seeds of $S$. spectabilis (-)-spectalinine (4) and (-)-6-iso-carnavaline (5). In the same year, Mulchandani and Hassarajani ${ }^{22}$ isolated the firstly described alkaloid cassinicine (6-dodecylacetyl-3-hydroxy-2methylpiperidine) (6) from the seeds of S. spectabilis.

In 1992, a new piperidine alkaloid 2-methyl-3-hydroxy6-(13-tetradecyl-acetyl)-piperidine (7) was isolated from the flowers of $S$. spectabilis cultivated in Egypt, however, its absolute configuration was never determined..$^{23}$ Three years later, in 1995, Bolzani et al. ${ }^{10}$ isolated four new piperidine alkaloids (-)-spectaline (8), leptophyllin A (9), 3-O-acetylleptophyllin A (10) and leptophyllin B (11), along with previously described carnavaline (12), found for the first time by Lythgoe and Vernenge, ${ }^{24}$ from the leaves of Cassia carnaval. Both leptophyllin A and 3-O-acetylleptophyllin A show a selective cytotoxic activity against a DNA-reparing mutant $S$. cerevisiae..$^{24,25}$

In 2003, Kamo et al. ${ }^{11}$ isolated two derivatives of (+)-6-iso-cassine from $S$. spectabilis named spectamine A ( $O$-benzoyl) (13) and B ( $O$-acetyl) (14). Compound 13 displays significant anti-inflammatory activities, acting on the inhibition of superoxide anion of macrophages. On the same year, Sriphong et al. ${ }^{13}$ reisolated spectamine A ((3R)-benzoyloxy-(2R)-methyl-(6R)-(11'-oxododecyl)piperidine) from the flowers of $S$. spectabilis, also exhibiting high cytoxicity against $\mathrm{KB}$ cell lines, a keratinforming tumor cell line $\mathrm{HeLa}\left(\mathrm{IC}_{50} 3.7 \mu \mathrm{g} \mathrm{mL} \mathrm{m}^{-1}\right)$.

On the following year, Viegas Junior et al. ${ }^{14}$ isolated three

Table 1. Secondary metabolites identified from Senna spectabilis

\begin{tabular}{|c|c|c|c|c|c|}
\hline & Leaves & Seeds & Flowers & Green fruits & Stem and roots \\
\hline Alkaloids & $\begin{array}{c}1,2,3,8,9,10,11,12 \\
13,14,20,21\end{array}$ & $4,5,6$ & $7,15,16,17,19$ & $15,16,17,18,19$ & - \\
\hline Pentacyclic triterpenes & $\begin{array}{c}22,23,24,25,26,27 \\
28,29\end{array}$ & - & $\begin{array}{c}22,23,24,25,26,27 \\
28,29\end{array}$ & $\begin{array}{c}22,23,24,25,26,27 \\
28,29\end{array}$ & - \\
\hline Steroids & $\mathbf{3 0},{ }^{\mathrm{a}} \mathbf{3 1}{ }^{\mathrm{a}}$ & - & $\mathbf{3 0},{ }^{\mathrm{a}} \mathbf{3 1},{ }^{\mathrm{a}} \mathbf{3 2}$ & $30,{ }^{\mathrm{a}} 31^{\mathrm{a}}$ & - \\
\hline Pyrones & - & - & $\mathbf{3 3}, \mathbf{3 4}, \mathbf{3 5}^{\mathrm{b}}$ & - & - \\
\hline Anthraquinones & 36, 37, 38 & - & $\mathbf{3 8}{ }^{\mathrm{b}} \mathbf{3 9}^{\mathrm{b}}$ & - & - \\
\hline Flavanoids & 40,41 & $42,43,44$ & - & 40,41 & - \\
\hline Miscellaneous & 48 & $47,46,47$ & 49 & 49 & 48 \\
\hline
\end{tabular}

${ }^{\mathrm{a}}$ Free and in glycosylated forms; ${ }^{\text {bflower buds. }}$ 
<smiles>CC(=O)CCCC[C@H]1CC[C@@H](O)[C@@H](C)N1</smiles><smiles>C[C@H](O)CCCCC[C@H]1CC[C@@H](O)[C@@H](C)N1</smiles><smiles>CC(=O)CCCCC1CCC(O)C(C)N1</smiles>

(7)<smiles>CC(=O)O[C@H]1CC[C@@H](CCCCC(C)CC(O)CO)N[C@@H]1C</smiles><smiles>CC(=O)CCCC[C@H]1CC[C@@H](OC(=O)c2ccccc2)[C@@H](C)N1</smiles>

(13)<smiles>CC(=O)CCCC[C@@H]1CC[C@@H](O)[C@@H](CO)N1</smiles><smiles>CC(=O)CCCC[C@H]1CC[C@@H](O)[C@@H](C)N1</smiles><smiles>C[C@H](O)CCCCC[C@H]1CC[C@@H](O)[C@@H](C)N1</smiles><smiles>CC(=O)CCCC[C@H]1CC[C@@H](O)[C@@H](C)N1</smiles>

(8)

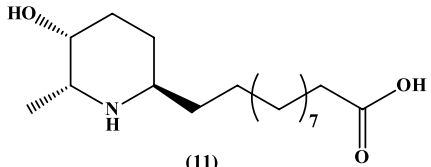

(11)<smiles>CC(=O)CCCC[C@H]1CC[C@@H](OC(C)=O)[C@@H](C)N1</smiles>

(14)<smiles>CC(=O)CCCC[C@H]1CC[C@@H](O)[C@@H](C)N1</smiles><smiles>CC(=O)CCCC[C@H]1CC[C@@H](O)[C@@H](C)N1</smiles><smiles>CC(=O)CCCC[C@H]1CC[C@@H](O)[C@@H](C)N1</smiles><smiles>C[C@H]1N[C@H](CCC(C)(C)CC(O)CO)CC[C@H]1O</smiles>

(9)<smiles>CC(O)CCCC[C@H]1CC[C@@H](O)[C@H](C)N1</smiles>

(15)<smiles>CC(=O)CCCC[C@H]1CC[C@@H](O)[C@@H](CO)N1</smiles>

(19)<smiles></smiles>

Figure 1. Chemical structures of alkaloids isolated from aerial parts of S. spectabilis (1-21).

new piperidine alkaloids (-)-3-O-acetylspectaline (15), (-)-7-hydroxyspectaline (16) and 6-iso-spectaline (17) from the flowers and immature fruits of $S$. spectabilis.

Both 6-iso-spectaline and (-)-3-O-acetylspectaline showed a promising antinociceptive activity, inhibition of lipid peroxidation, moderate inhibition against COX-1 and 2 and selective cytotoxic against $S$. cerevisiae strains, indicating a potential antitumoral activity. ${ }^{10,12,14,26,27}$ 6-Isospectaline, also demonstrated central nervous system (CNS) depressant activity and anticonvulsant properties, as well as modulation for the treatment of neurodegenerative diseases. ${ }^{16}$
In 2007, Viegas Junior et al. ${ }^{28}$ isolated (+)-3-O-feruloylcassine (18) from the green fruits of $S$. spectabilis. This metabolite shows moderate antiinflammatory activity (40-70\%) when compared to commercial standards celecoxib, rofecoxib and aspirin; moderate inhibition of COX-1 (40\%) and marginal inhibition of COX-2 enzymes. Recently, Viegas Junior et al..$^{5}$ also isolated a new piperidine alkaloid (-)-7-hydroxycassine (19) from the flowers and immature fruits of $S$. spectabilis.

Sriphong et al..$^{13}$ also found low abundance pyridine alkaloids from the flowers of $S$. spectabilis, named 5-hydroxy-2-methyl-6-(11'-oxododecyl)-pyridine (20) 
and 5-hydroxy-2-methyl-6-(11-oxododecyl)-pyridine- $N$ oxide (21), the latter showing significant cytotoxic activity against $\mathrm{KB}$ cell lines $\left(\mathrm{IC}_{50} 2.0 \mu \mathrm{g} \mathrm{mL}^{-1}\right)$.

\section{Pentacyclic triterpenes}

Although phytochemical studies of S. spectabilis have begun in the late 70's, the first report of terpenes occured only in 2010, when Oliveira and co-workers isolated and identified eight pentacyclic triterpenes, molecules with similar chemical structure to steroids. ${ }^{29-31}$

These secondary metabolites, isolated from leaves, flowers and green fruits of $S$. spectabilis, were found in both mixture ( $\alpha$-amyrin (22), $\beta$-amyrin (23), ursolic acid (24) and oleanolic acid (25)) and pure forms (betulinic acid (26), lupeol (27), cycloeucalenol (28), friedelin (29)), showing biological activity in animal and human models (Figure 2). ${ }^{31}$

Lupeol (27), also called lup-20-(29)-en-3 $\beta$-ol, is widely found in fruits and vegetables as well as in a variety of medicinal plants such as Tamarindus indica, Emblica officinalis and Celastrus paniculatus. ${ }^{32,33}$ This triterpene shows several pharmacological activities, acting against inflammation, several cancer cell lines, such as human lung carcinoma and human colorectal adenocarcinoma, arthritis, heart diseases, diabetes and renal/liver toxicity. ${ }^{34-37}$ Recent studies also reported the effect of lupeol on the reduction of blood cholesterol levels and also for chemoprevention, the latter being mainly associated with anti-proliferative effect against different strains of cancer cells and low toxicity to cells and healthy tissues. ${ }^{38-40}$

Friedelin (29), also isolated from Kokoona zeylanica, Secamone afzelii and Prunus turfosa, is a 3-keto derivative of friedelane also known as friedelan-3-one. ${ }^{41-43}$ It is reported to have anti-inflammatory activity against paw edema induced by carrageen and histamine ${ }^{44}$ and, in recent studies, this metabolite also exhibits analgesic and antipyretic properties, demonstrating strong oral and facial antinociceptive features. ${ }^{45,46}$

Cycloeucalenol (4,14-dimethyl-( $3 \beta, 4 \alpha, 5 \alpha)-9,19$ cycloergost-24-(28)-en-3-ol) (28), also isolated from various medicinal plants, promotes a moderate increase in the right atrial contraction force, as well as a decrease in the left atrium into the coronary tissue on in vitro tests using Winstar rats, proving to be a potential drug in the treatment of cardiovascular diseases. ${ }^{47-50}$

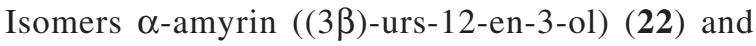

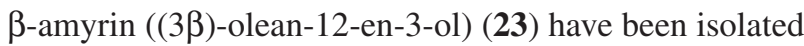
from several plants and algae species, ${ }^{51,52}$ exhibiting anti-

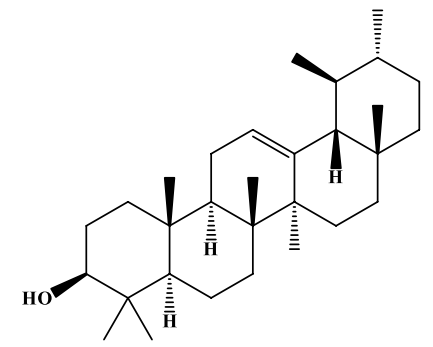

(22)

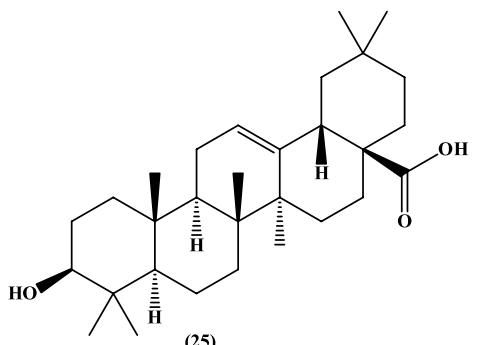

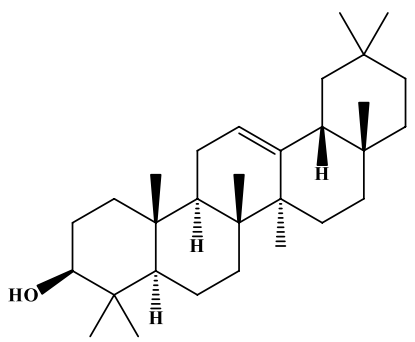

(23)

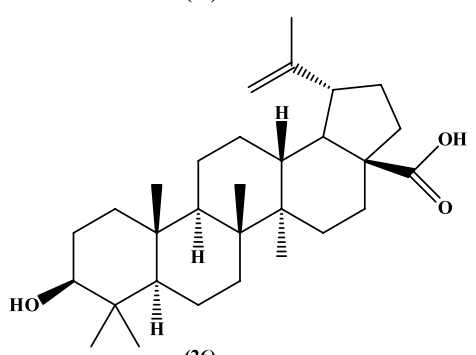

(26)

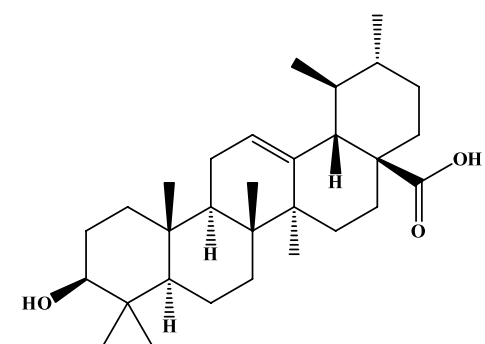

(24)

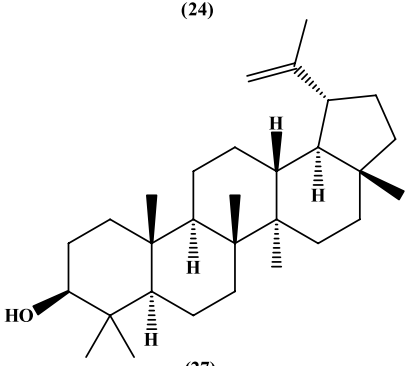

(27)
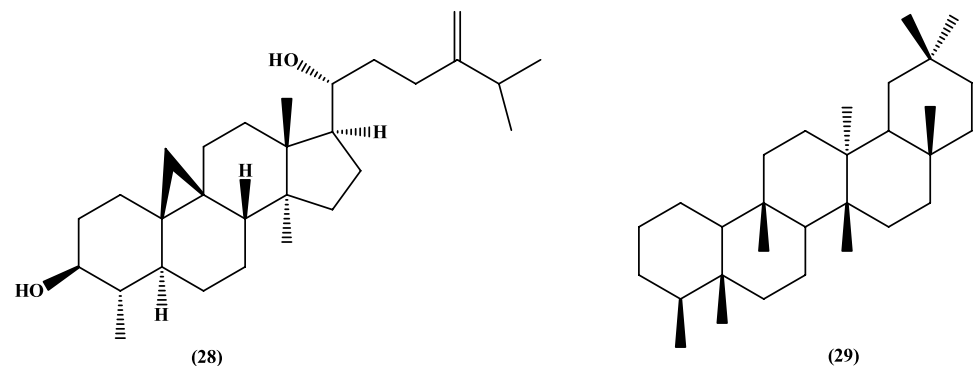

Figure 2. Chemical structure of pentacyclic triterpenes isolated from S. spectabilis (22-29). 
inflammatory, antinociceptive, antioxidant, antipruritic, antibacterial and gastro-hepatoprotective properties. ${ }^{52-59}$ More recently, Jeon et al..$^{60}$ also showed that $\beta$-amyrin improves general sleep behavior induced by pentobarbital model, through the activation of Gamma-AminoButyric Acid (GABAergic) neurotransmission system in the brain.

Betulinic (26), ursolic (24) and oleanolic (25) acids are found in several species of the kingdom Plantae, including medicinal herbs and fruits from the human diet. ${ }^{31,61,62}$ Betulinic acid, isolated from leaves, fruits and flowers of Senna, is a highly bioactive triterpene, displaying antiHIV, antibacterial, antimalarial and anti-inflammatory effects. ${ }^{5,31,63-65}$ Commonly known as $3 \beta$-hydroxy-lup20-(29)-en-28-oic acid, this triterpene promises to be a potential drug for cancer treatment due to its cytotoxicity against various cancer cell lines (lung, ovarian, neuroand glioblastoma and head/neck carcinomas), selective inhibition of human melanoma, apoptosis induction in human neurobastoma and low toxicity to healthy cells. ${ }^{66}$

Ursolic acid, found either free or bounded to saponins, is a common constituent of fruits from human diet such as apple, guava and blueberry. ${ }^{31,67}$ Known as $3 \beta$-hydroxy-urs12-en-28-oic-acid, this metabolite has protective properties against fatty liver induced by high-lipid diet and liver injury as well as anti-bacterial, anti-inflammatory and antioxidative properties. ${ }^{67-71}$

Oleanolic acid, an ursolic acid isomer, is found in over 1620 plant species. $^{72}$ This compound, predominant in the Oleaceae family, exhibits several biological activities, such as hepatoprotective, anti-inflammatory, antioxidant and anti-tumor. ${ }^{73}$ Gao et al. ${ }^{74}$ also described this compound as an alternative drug for the regulation of metabolic disorders, with increased expression of lipoprotein lipase, insulin sensitivity and dyslipidemia. Often, this metabolite is studied in association with ursolic acid, demonstrating relevant pharmacological properties. ${ }^{75}$ More recently, Jimenez-Arellanes et al. ${ }^{76}$ revealed that both isomers act in synergism against Mycobacterium tuberculosis, promoting a rapid elimination of the pathogen.

\section{Steroids}

In 1977, Mulchandani and Hassarajani ${ }^{22}$ reported the presence of two well-known steroids isolated from the plant's aerial portions: stigmasterol (30) and $\beta$-sitosterol (31). Found as a mixture, this phytosterols are presented in both free and glycosylated form on the leaves, flowers and green fruits of S. spectabilis, possessing similar spectroscopic properties to other steroids (Figure 3). ${ }^{31}$

Stigmasterol (3ß-hydroxy-24-ethyl-5,22-cholestadiene) (30) is found in numerous roots from trees and grass plants, as well as algae and fungi. ${ }^{22,77,78}$ This steroid was firstly reported in 1907 by Windhaus and Hauth, ${ }^{79}$ isolated from Calabar beans (Physostigma venenosum) and its absolute configuration was determined in 1963 by Fitches. ${ }^{80}$

Stigmasterol's anti-inflammatory potential has been extensively studied, showing significant results in several animal models. ${ }^{81-84}$ This metabolite also shows significant effect on the inhibition of the chemical nociceptors induced by acetic acid, being dose dependent for the reduction of time spent in pain behavior both in early and late phases using the formalin test. ${ }^{84}$ Moreover, the steroid shows antimicrobial properties against Bacillus cereus, Escherichia coli, Staphylococcus aureus, Salmonella typhimuriumand and Candida albicans as well as low activity against P388 murine leukemia cells in cytotoxicity studies..$^{82,85}$

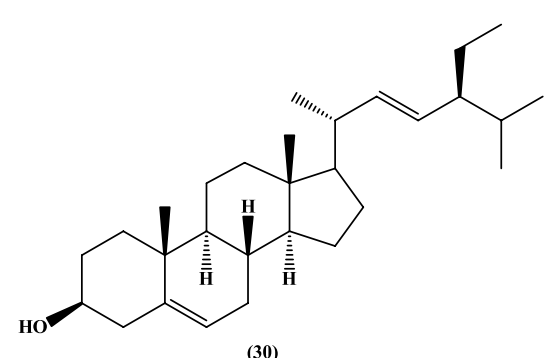

(30)

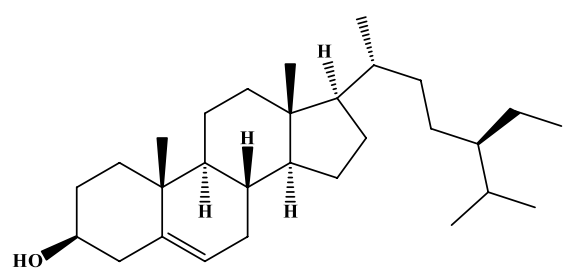

(31)

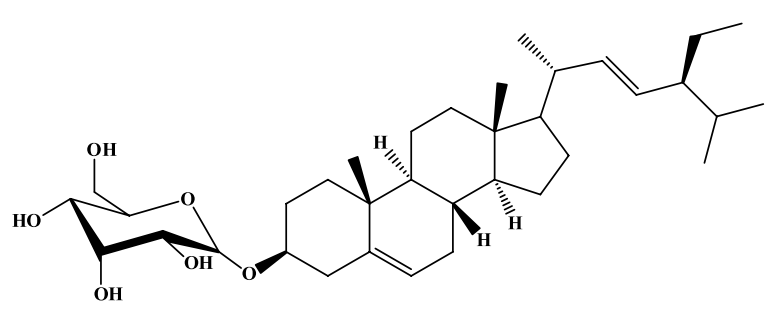

(32)

Figure 3. Sterols isolated from $S$. spectabilis (30-32). 
<smiles>O=C(O)c1cc(=O)cc(C(=O)O)o1</smiles>

(33)<smiles>COC(=O)c1cc(=O)cc(C(=O)OC)o1</smiles>

(34)<smiles>COC(=O)c1cc(=O)cc(C(=O)O)o1</smiles>

(35)

Figure 4. Chemical structures of $\gamma$-pyrones isolated from S. spectabilis (33-35).

$\beta$-Sitosterol ( $\alpha$-dihydrofucosterol) (31) is the most abundant phytosterol on human diet and possess significant effect in relieving menopausal symptoms and reducing blood cholesterol levels by blocking the intestinal uptake. $^{86-88}$

Encountered in leaves, flowers and fruits, largely distributed throughout the Plantae kingdom, ${ }^{89-91}$ this metabolite has a similar structure to estradiol and cholesterol, showing important anti-inflammatory and analgesic properties, ${ }^{92-94}$ as well as antitumoral effects, such as minimizing symptoms of prostatic hyperplasia. ${ }^{95}$ In recent study, it also has a significant concentrationdependent inhibition against induced-Epstein-Barr virus antigen, at low toxicity rates. ${ }^{96}$

The last sterol reported was in 1992, when the 3-O-glucoside derivate of stigmasterol (32) was isolated from the flowers of $S$. spectabilis by Backheet and El-Sayyad, ${ }^{23}$ along with a firstly reported anthraquinone (39) described below.

\section{Pyrones}

The first pyrones reported from the flower ethanolic extract of S. spectabilis were identified by Mallaiah et al., ${ }^{97}$ in 1984, isolating chelidonic acid (33) and the dimethylester analogue dimethylchelidonate (34), two $\gamma$-pyrones with anti-allergic activity (Figure 4). Chelidonic acid presents, through passive peritoneal anaphylaxis method on male rats, a potential positive result for anti-allergic activity when compared with the standard used disodium cromoglycate (DSCG) commercially available for the treatment of asthma from allergic origin.

Four years later, in 1988, Ashok and Sarma ${ }^{98}$ re-isolated both pyrones previously identified, along with the $\gamma$-pyrone monomethyl chelidonate (35) (Figure 4), being the first report of its isolation from a natural source. Compound $\mathbf{3 5}$ showed a mild antifeedant activity using 6 hours pre-starved fourth instar larvae of Spondoptera litura.

\section{Anthraquinones}

The first anthraquinones isolated from $S$. spectabilis were 1,3,8-trihydroxy-2-methylanthraquinone (36) and physcion (1,8-dihydroxy-6-methoxy-3-methylanthraquinone) (37) (Figure 5), found on the methanolic extract of the plant's leaves. ${ }^{22}$ Compounds 36 and 37 exhibited antimicrobial activity against Staphylococcus aureus, Staphylococcus albus, Sarcina lutea, Mycobacterium tuberculosis and Bacillus subtilis, while compound $\mathbf{3 8}$ also shows strong antifungal activity against Candida albicans, Cryptococcus neoformans and Trichophyton mentagrophytes, as well as beneficial effects for the treatment of cervical carcinoma. ${ }^{99,100}$<smiles>Cc1c(O)cc2c(c1O)C(=O)c1c(O)cccc1C2=O</smiles>

(36)<smiles>Cc1cc(O)c2c(c1)C(=O)c1c(O)cccc1C2=O</smiles>

(38)<smiles>COc1cc(O)c2c(c1)C(=O)c1c(O)cc(C)cc1C2=O</smiles>

(37)<smiles>Cc1cc(O)c2c(c1)C(=O)c1cc(O)cc(O)c1C2=O</smiles>

(39)
Figure 5. Chemical structures of anthraquinones isolated from $S$. spectabilis (36-39).

In 1988, Ashok and Sarma ${ }^{98}$ reisolated the polyhydroxy anthraquinone physion, along with chrysophanol (1,8-dihydroxy-3-methylanthraquinone) (38), a newly descried anthraquinone for $S$. spectabilis that shows several biological activities, including anticancer, hepatoprotective, and antimicrobial properties. ${ }^{101-103}$

Two years later, in 1992, Backheet and El-Sayyad ${ }^{23}$ isolated the last anthraquinones identified for this species's leaves and flower buds, being two known compounds physcion (37) and chrysophanol (38) and the firstly described anthraquinone emodin (1,6,8-trihydroxy3 -methylanthraquinone) (39) (Figure 5). Emodin is a highly active compound which displays several biological activities such as immunosuppressive, antimicrobial, laxative, anti-atherosclerotic, laxative and anti-inflammatory. ${ }^{92,104-107}$ Moreover, this 
<smiles>O=c1cc(-c2ccc(O)c(O)c2)oc2cc(O)cc(O)c12</smiles><smiles>COc1c(-c2ccc(O)c(O)c2)oc2cc(O)cc(O)c2c1=O</smiles><smiles>COc1ccc(-c2cc(=O)c3cc(OC4C[C@H](O)[C@@H](O)CO4)ccc3o2)cc1</smiles>

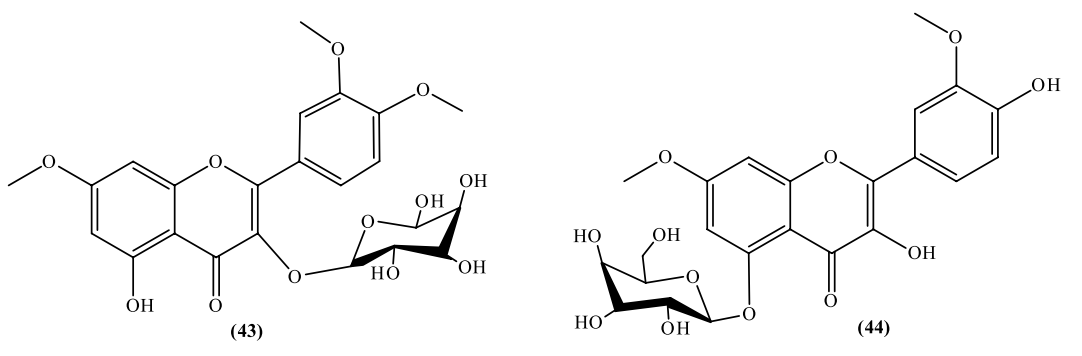

Figure 6. Chemical structures of flavonoids and flavones isolated from S. spectabilis (40-44).

anthraquinone also exerts antitumor activity against different human cancers and attenuates the anaphylactic reaction in immunoglobulin-E-sensitized mice. ${ }^{108,109}$

\section{Flavonoids}

Viegas Junior et al. ${ }^{5}$ reported the isolation of two flavonoids luteolin (40) and methoxyluteolin (41) (Figure 6) from the flowers and green fruits of $S$. spectabilis. Compound $\mathbf{4 0}$ possesses anti-inflammatory, antioxidant, anticancer activities, as well as therapeutic effect in mice liver injury by tetrachloromethane and ethanol. ${ }^{110,111}$

Singh and Singh ${ }^{112}$ study on $S$. spectabilis aerial portions led to the isolation of two flavone glycosides 6-hydroxy4'-methoxy-flavone-6- $O$-arabinopyranoside (42) and 3,5-dihydroxy-7,3', 4'-trimethoxy-flavone-3-Oarabinopyranoside (43) from the ethanolic extract of the plant's seeds (Figure 6). At the same year, flavone glucoside 5,4 '-dihydroxy-7,3'-dimethoxyflavone-5- $O-\beta-D(+)$ glucopyranoside (44) was also isolated from $S$. spectabilis's seeds by Sinha et al. ${ }^{113}$

\section{Miscellaneous compounds}

In 1984, two higher fatty acids tetratriacontanylpalmitate (45) and tetratriacontanyl-nonadecanoate (46), and one chromone glycoside 2"-O-glycoside of 5-acetonyl-7-hydroxy-6-glucosyl-2-methyl chromone (47)

were isolated from the seeds of S. spectabilis (Figure 7), ${ }^{114}$ metabolites that potentially provide energy sources for plant's seeds. ${ }^{114}$

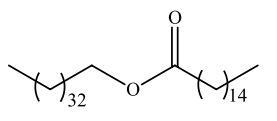

(45)

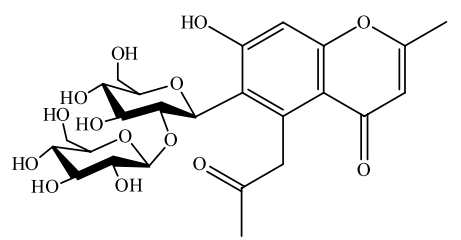

(47)<smiles>Cn1c(=O)c2c(ncn2C)n(C)c1=O</smiles>

(48)<smiles>CCNCOC(=O)NC</smiles>

(46)

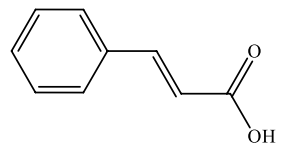

(49)
Figure 7. Chemical structures of miscellaneous compounds from S. spectabilis (45-49).

In 2010, caffeine (1,3,7-trimethylpurine-2,6-dione) (48), which is the most common methylxanthine, was identified from the ethanolic extract of leaves, stem and roots. ${ }^{6}$ This compound is widely used in beverages, cosmetics and medicine and is considered a psychotropic 
substance. ${ }^{115}$ For cosmetic application, compound $\mathbf{4 8}$ is used for its antioxidant activity, for UV protection and the stimulation of hair growth. ${ }^{116}$

In 2013, Viegas Junior et al. ${ }^{5}$ reported the isolation of substances from two distinct chemical classes: previously described flavonoids (40) and (41) and one phenylpropenoic acid known as trans-cinnamic acid (49), the latter having chemopreventive properties such as inhibitory effect against metastasis of adenocarcinoma human cells A 549.5,117

\section{Conclusions}

This review outlines the constituents and pharmacological activities reported for $S$. spectabilis. According to Figure 8, studies involving the discovery of new metabolites in this species have increased since the first review published 10 years ago. This indicates the importance of rationally explore and report, the molecular constituents of this plant and their biological activities.

Studies regarding leaves, green fruits, stem, roots and flowers revealed a great diversity of bioactive metabolites from $S$. spectabilis, enabling the collection of botanical, chemical composition, biological activities and microbial studies.

Piperidine alkaloids (Figure 9) are, by far, the major constituents in $S$. spectabilis aerial parts, protecting the plant against pathogens and predators, as well as showing a long list of pharmacological activities.

The isolation of only four anthraquinones remains unexplained, as the genus is known to be a rich source of this compound class.

Several possibilities arose to justify this evidence: the difficulties associated to the exploration of complex chemical profiles, due to the lack of modern technology at the time when these chemotypes where reported, preventing

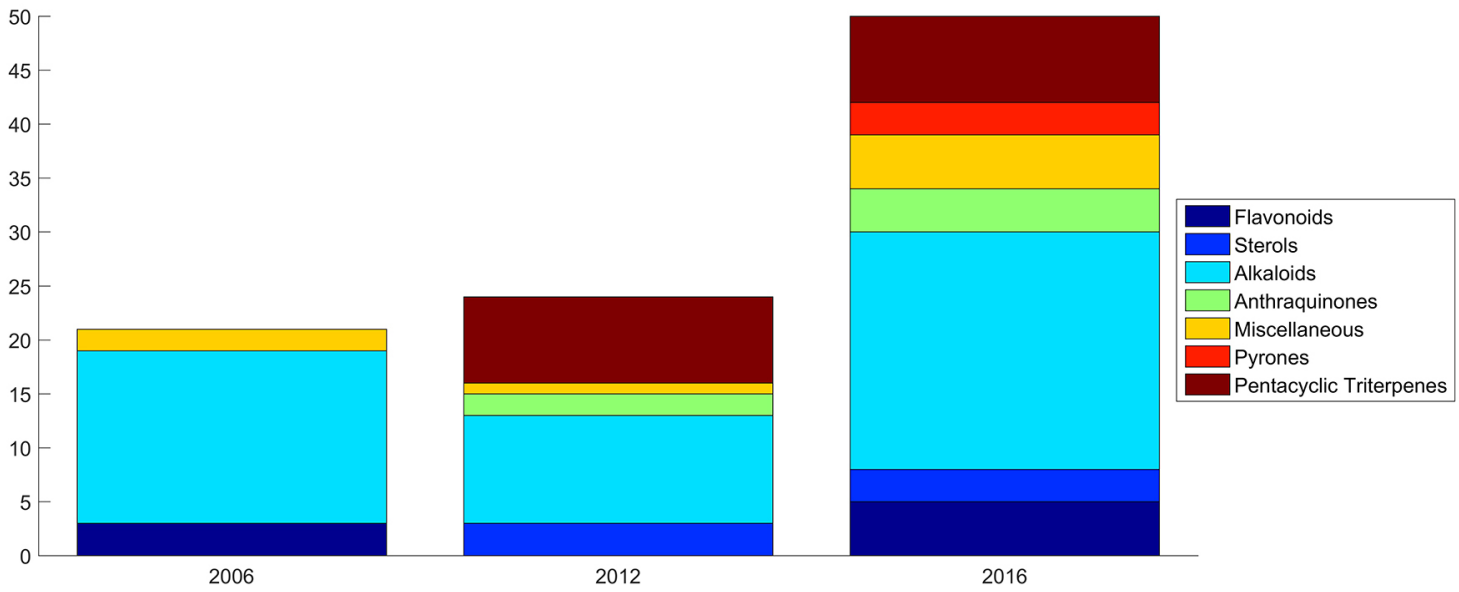

Figure 8. Number of metabolites from S. spectabilis described in previous reviews (2006 118 and $\left.2012^{3}\right)$.

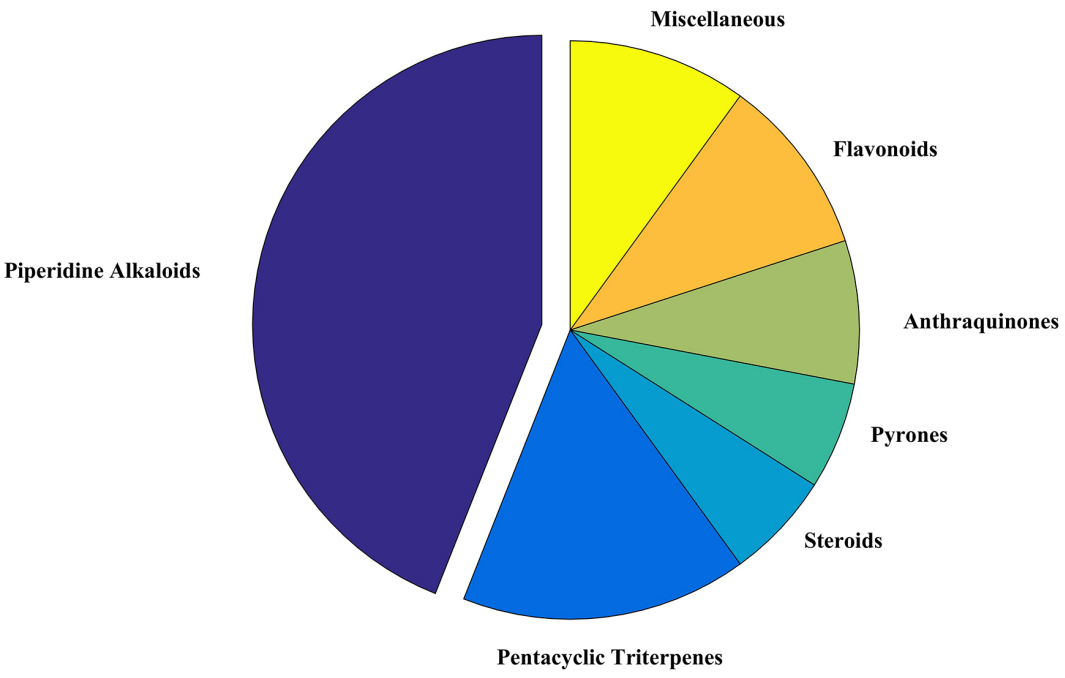

Figure 9. Class distribution for metabolites isolated from S. spectabilis. 
their detection in low concentrations and, the goals of the research groups, aiming for specific compounds, based solely on specific biological activities that may lead to overlook this compounds.

Advances in analytical techniques and computational algorithms have improved the identification of new bioactive compounds and can be extremely useful for further elucidation of secondary metabolites from $S$. spectabilis as well as for their microbe community. Among those, we highlight dereplication techniques associated with multivariate analysis, which leads to fast identification of known compounds in crude extracts, accelerating the selection of biologically promising molecules and the identification of important known chemotypes.

The study of endophytic and rhizosphere fungi allows the understanding of interaction between species, as well as the chemical profile of this microorganisms, being a novel source of new secondary metabolites, aiming specific biological targets for medical uses.

\section{Supplementary Information}

Supplementary information is available free of charge at http://jbcs.sbq.org.br as PDF file.

\section{Acknowledgments}

The authors wish to acknowledge the São Paulo State Research Foundation (FAPESP) within the Biota-FAPESPThe Biodiversity Virtual Institute Program (www.biota.org.br) (2011/50816-1), PhD scholarship awarded to D. M. S. (2014/05935-0) and CEPID Program through CIBFar Project (2013/07600-3), and CAPES and CNPq for grants and research fellowships.

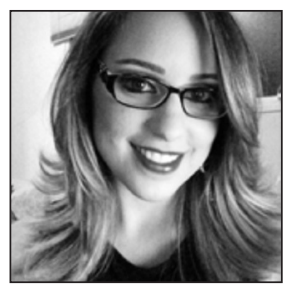

Denise M. Selegato is graduated in Pharmacy-Biochemistry at São Paulo State University (2013) and is currently a PhD student in the Nucleus of Bioassays, Biosynthesis and Ecophysiology of natural products $(N u B B E)$ from the same University. Her field of interest is plant science, particularly NMR-based metabolomics, chemometric analysis and the development of new in silico techniques for dereplicating complex matrices. Her research interest focuses on microbes isolated from Senna spectabilis's rhizosphere, aiming to apply methodologies to activate silenced genes, such as co-culture, One Strain, Many Compounds (OSMAC) and epigenetics.

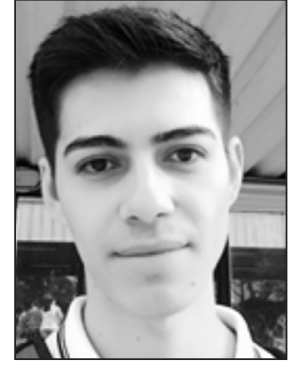

Afif Felix Monteiro got his degree in Chemistry in 2011 and received his master degree in chemistry (Organic Chemistry) from Federal University of Goiás in 2014. He is currently working on his PhD thesis at Institute of Chemistry from São Paulo State University. His research interest focuses on metabolomic investigations of mono and co-cultured endophytic and rhizosphere fungi associated with Senna spectabilis, and also encompasses the elicitation of targeted natural products, together with the study of fungal biotransformation of secondary metabolites and the optimization of culture conditions for metabolites production by applying factorial design and chemometric tools.

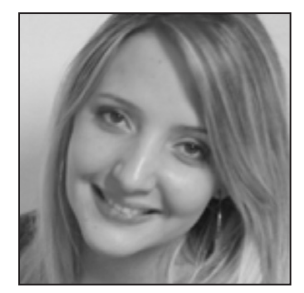

Natália Carolina Vieira was born in Araraquara, São Paulo, Brazil in 1990. She is graduated in chemistry in 2013 at State University of São Paulo and received her $M S c$ in Organic Chemistry in 2016 at the same University. Currently, she is working on her PhD thesis in Natural Products at State University of São Paulo. Her recent research has focused on studying the metabolic variation and bioactive compounds of rhizosphere fungi from Senna spectabilis.

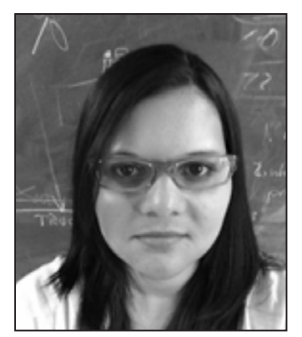

Patrícia Cardoso graduated in chemistry in 2007, received her master's degree in Chemistry (emphasis in Organic Chemistry) in 2010 and holds her PhD from São Paulo State University "Júlio de Mesquita Filho” (UNESP). Her research interest lies in chemistry of natural products focusing on techniques in the context of systems biology aimed at understanding the relationship between plant/microorganism in the interface known as the rhizosphere.

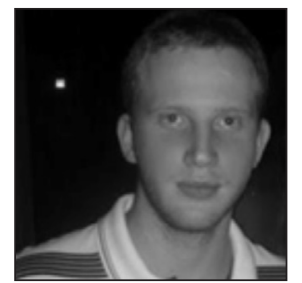

Victor Damasceno Pavani was born in Jaboticabal, São Paulo, Brazil in 1987. He graduated in Chemistry in 2011 at Chemistry Institute at State University of São Paulo "Julio de Mesquita Filho" (IQ-UNESP) and received his $M S c$ in Chemistry (Organic Chemistry) in 2013 from de same 
university. Nowadays, he is working on his $P h D$, focusing on co-culture of microorganisms isolated from Senna spectabilis's rhizosphere.

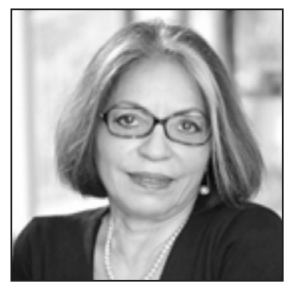

Vanderlan Bolzani graduated in Pharmacy in 1973 at the Federal University of Paraíba, received her master degree in 1977 at São Paulo University and her PhD degree in 1982 from the same University under guidance of Professor Otto Richard Gottlieb. After a post-doctorate at Virginia Polytechnic Institute, she joined the São Paulo State University (UNESP). Since 2003, is member of the Biota-FAPESP Program Coordination and is Currently Director of the UNESP Technology Transfer Office. Her field of interest is plant science, particularly biosynthesis of piperidine alkaloids, metabolomics of medicinal plants and the bioactivity and function of secondary metabolites and peptides from plants. Has published more than 203 articles (Index $h=26,2522$ citations), 5 book chapters and 7 patents.

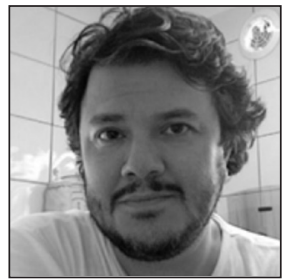

Ian Castro-Gamboa graduated in Chemistry (emphasis on Organic Chemistry) in 1994 at the Universidad de Costa Rica, and received his $P h D$ in 2000 at Federal University of São Carlos. After a post-doctorate in Electrochemistry, he joined the São Paulo State University (UNESP) as Assistant Professor. His field of interest is plant science, particularly metabolomics, NMR-dereplication, development of analytical techniques and hyphenated techniques. Nowadays, he is coordinator of the Chemistry Institute NMR platform.

\section{References}

1. Rodrigues, R. S.; Flores, A. S.; Miotto, S. T. S.; Baptista, L. R. M.; Acta Bot. Bras. 2005, 19, 1.

2. International Legume Database \& Information Service, November 2005, Version 10.01. Retrieved December 20, 2007. Available at http://www.ildis.org/, accessed in December 2016.

3. Jothy, S. L.; Torey, A.; Darah, I.; Choong, Y. S.; Saravanan, D.; Chen, Y.; Latha, L. Y.; Deivanai, S.; Sasidharan, S.; Molecules 2012, 17, 10292.

4. Sado, M.; Tavares, A. R.; Chu, E. P.; Afr. J. Biotechnol. 2014, 13, 3567.

5. Viegas Jr., C.; Pivatto, M.; Rezende, A.; Hamerski, L.; Silva, D. H. S.; Bolzani, V. S.; J. Braz. Chem. Soc. 2013, 24, 230.
6. Silva, F. O.; Oliveira, I. R. O.; Silva, M. G. V.; Quim. Nova 2010, 33, 1874.

7. Chapla, V. M.; Zeraik, M. L.; Ximenes, V.; Zanardi, L. M.; Lopes, M.; Cavalheiro, A. J.; Silva, D. H. S.; Young, M. C. M.; Fonseca, L.; Bolzani, V. S.; Araújo, A. R.; Molecules 2014, 19, 6597.

8. Zanardi, L. M.; Bolzani, V. S.; Cavalheiro, A. J.; Silva, D. H. S.; Trevisan, H. C.; Araújo, A. R.; Young, M. C. M.; Quim. Nova 2012, 35, 2233.

9. Selegato, D. M.; Freire, R. T.; Tannús, A.; Castro-Gamboa, I.; J. Braz. Chem. Soc. 2016, 27, 1421.

10. Bolzani, V. S.; Gunatilaka, A. A. L.; Kingston, D. G. I.; Tetrahedron 1995, 51, 5929.

11. Kamo, T.; Machara, K.; Sato, K.; Hirota, M.; Heterocycles 2003, 60, 1303.

12. Moreira, M. A. S.; Viegas Jr, C.; Miranda, A. L. P.; Barreiro, E. J.; Bolzani, V. S.; Planta Med. 2003, 69, 795.

13. Sriphong, L.; Sotanaphun, U.; Limsirichalkul, S.; Wetwitayaklung, P.; Chaichantipyuth, C.; Pummangura, S.; Planta Med. 2003, 69, 1054.

14. Viegas Jr., C.; Bolzani, V. S.; Furlan, M.; Furlan, M. S.; Barreiro, E. J.; Young, M. C. M.; Tomazela, D.; Eberlin, M. N.; J. Nat. Prod. 2004, 67, 908.

15. Alexandre-Moreira, M. S.; Viegas Jr., C.; de Miranda, A. L. P.; Bolzani, V. S.; Barreiro, E. J.; Planta Med. 2007, 69, 795.

16. Silva, F. O.; Silva, M. G. V.; Feng, D.; de Freitas, R. M.; Fitoterapia 2011, 82, 255.

17. Christofidis, I.; Welter, A.; Jadot, J.; Tetrahedron 1976, 33, 977.

18. Highet, R. J.; Highet, P. F.; J. Org. Chem. 1966, 31, 1275.

19. Rice, W. Y.; Coke, J. L.; J. Org.Chem. 1966, 31, 1010.

20. Mello, G. M. A.; Silva, M. C. R.; Guimarães, T. P.; Pinheiro, K. M.; da Matta, C. B. B.; de Queiroz, A. C.; Pivatto, M.; Bolzani, V. S.; Alexandre-Moreira, M. S.; Viegas Jr., C.; Phytomedicine 2013, 21, 277.

21. Christofidis, I.; Welter, A.; Jadot, J.; Tetrahedron 1977, 33, 3005.

22. Mulchandani, N. B.; Hassarajani, S. A.; Planta Med. 1977, 32, 357.

23. Backheet, E. Y.; El-Sayyad, S. M.; Bulletin of the Faculty of Science, Assiut University 1992, 21, 129.

24. Lythgoe, D.; Vernenge, M. J.; Tetrahedron Lett. 1967, 12, 1133.

25. Lythgoe, D.; Busch, A.; Schvarzberg, N.; Vernenge, M. J.; An. Asoc. Quim. Argent. (1921-2001) 1962, 60, 317.

26. Silva, F. O.; Silva, M. G. V.; Cerqueira, G. S.; Sabino, E. B.; Almeida, A. A. C.; Costa, P.; Freitas, R. M.; J. Young Pharm. 2011, 3, 232.

27. Viegas Junior, C.; Alexandre-Moreira, M. S.; Fraga, C. A. M.; Barreiro, E. J.; Bolzani, V. S.; de Miranda, A. L. P.; Chem. Pharm. Bull. 2008, 54, 407.

28. Viegas Junior, C.; Silva, D. H. S.; Pivatto, M.; de Rezende, A.; Castro-Gamboa, I.; Bolzani, V. S.; Nair, M. G.; J. Nat. Prod. 2007, 70, 2026. 
29. Jäger, S.; Trojan, H.; Kopp, T.; Laszczyk, M. N.; Scheffler, A.; Molecules 2009, 14, 2016.

30. Santos, F. A.; Frota, J. T.; Arruda, B. R.; de Melo, T. S.; da Silva, A. A. C. A.; Brito, G. A. C.; Chaves, M. H.; Rao, V. S.; Lipids Health Dis. 2012, 11, 98.

31. Silva, F. O.; de Oliveira, I. R.; de Vasconcelos Silva, M. G.; Braz-Filho, R.; Quim. Nova 2010, 33, 1874.

32. Abdullahi, S. M.; Musa, A. M.; Abdullahi, M. I.; Sule, M. I.; Sani, Y. M.; Scholars Acad. J. Biosci. 2013, 1, 18.

33. Siddique, H. R.; Saleem, M.; Life Sci. 2011, 88, 285.

34. Avin, B. R. V.; Prabhu, T.; Ramesh, C. K.; Vigneshwaran, V.; Riaz, M.; Jayashree, K.; Prabhakar, B. T.; Biochem. Biophys. Res. Commun. 2014, 448, 1.

35. Saleem, M.; Cancer Lett. 2009, 285, 109.

36. Gallo, M. B. C.; Sarachine, M. J.; Int. J. Biomed. Pharma. Sci. 2009, 3, 46.

37. Singh, P.; Arora, D.; Shukla, Y.; Food Chem. Toxicol. 2017, 99 , 182.

38. Wu, S. B.; Su, J. J.; Sun, L. H.; Wang, W. X.; Zhao, Y.; Li, H.; Zhang, S. P.; Dai, G. H.; Wang, C. G.; Hu, J. F.; J. Nat. Prod. 2009, 73, 1898.

39. Chaturvedi, P. K.; Bhui, K.; Shukla, Y.; Cancer Lett. 2008, 263, 1.

40. Palanimuthu, D.; Baskaran, N.; Silvan, S.; Rajasekaran, D.; Manoharan, S.; Pathol. Oncol. Res. 2012, 18, 1029.

41. Sainsbury, M.; Phytochemistry 1970, 9, 2209.

42. El-Said, F.; Sofowora, E. A.; Salami, M. A.; Phytochemistry 1971, 10, 1940.

43. Gunatilaka, A. A. L.; Nanayakkara, N. P. D.; Uvais, M.; Sultanbawa, S.; Balasubramaniam, S.; Phytochemistry 1982, 21,2061

44. Shimizu, M.; Tommo, T.; Biol. Pharm. Bull. 1994, 15, 665.

45. Quintans, J. S. S.; Costa, E. V.; Tavares, J. F.; Souza, T. T.; Araújo, S. S.; Estevam, C. S.; Barison, A.; Cabral, A. G. S.; Silva, M. S.; Serafini, M. R.; Quintans-Júnior, L.; Rev. Bras. Farmacogn. 2014, 24, 60.

46. Antonisamy, P.; Duraipandiyan, V.; Ignacimuthu, S.; J. Pharm. Pharmacol. 2011, 63, 1070.

47. Kongkathip, P.; Dhumma-upakorn, P.; Kongkathip, B.; Chawananoraset, K.; Sangchomkaeo, P.; Hatthakitpanichakul, S.; J. Ethnopharmacol. 2002, 83, 95.

48. Nagasampagi, B. A.; Rowe, J.; Phytochemistry 1971, 10, 1101.

49. Haba, H.; Lavaud, C.; Harkat, H.; Alabdul Magid, A.; Marcourt, L.; Benkhaled, M.; Phytochemistry 2007, 68, 1255.

50. Koorbanallya, N.; Mulhollanda, D. A.; Crouchb, N.; Phytochemistry 2000, 54, 93.

51. Abdel-Raouf, N.; Al-Enazi, N. M.; Al-Homaidan, A. A.; Ibraheem, I. B. M.; Al-Othman, M. R.; Hatamleh, A. A.; Arab. J. Chem. 2015, 32.

52. Baby, S.; Johnson, A. J.; Govindan, B.; Phytochemistry 2015 , $114,66$.
53. Pinto, S. A. H.; Pinto, L. M.; Cunha, G. M.; Chaves, M. H.; Santos, F. A.; Rao, V. S.; Inflammopharmacology 2008, 16, 48.

54. Vitor, C. E.; Figueiredo, C. P.; Hara, D. B.; Bento, A. F.; Mazzuco, T. L.; Calixto, J. B.; Br. J. Pharmacol. 2009, 157, 1034.

55. Silva, K. A. B. S.; Paszcuk, A. F.; Passos, G. F.; Silva, E. S.; Bento, A. F.; Meotti, F. C.; Calixto, J. B.; Pain 2011, 152, 1872.

56. Chicca, A.; Marazzi, J.; Gertsch, J.; Br. J. Pharmacol. 2012, 167, 596.

57. Oliveira, F. A.; Lima-Junior, R. C.; Cordeiro, W. M.; VieiraJúnior, G. M.; Chaves, M. H.; Almeida, F. R.; Silva, R. M.; Santos, F. A.; Rao, V. S.; Pharmacol., Biochem. Behav. 2004, 78,719

58. Oliveira, F. A.; Vieira-Júnior, G. M.; Chaves, M. H.; Almeida, F. R.; Santos, K. A.; Martins, F. S.; Silva, R. M.; Santos, F. A.; Rao, V. S.; Planta Med. 2004, 70, 780.

59. Oliveira, F. A.; Chaves, M. H.; Almeida, F. R.; Lima, R. C.; Silva Junior, R. M.; Maia, J. L.; Brito, G. A.; Santos, F. A.; Rao, V. S.; J. Ethnopharmacol. 2005, 98, 103.

60. Jeon, S. J.; Park, H. J.; Gao, Q.; Lee, H. E.; Park, S. J.; Hong, R.; Jang, D. S.; Shin, C. Y.; Cheong, J. H.; Ryu, J. H.; Behav. Brain Res. 2015, 291, 232.

61. Puniani, E.; Cayer, C.; Kent, P.; Mullally, M.; Sánchez-Vindas, P.; Álvarez, L. P.; Cal, V.; Merali, Z.; Arnason, J. T.; Durst, T.; Phytochemistry 2015, 113, 73.

62. Srisurichan, S.; Pornpakakul, S.; Phytochem. Lett. 2015, 12, 282.

63. Li, F.; Goila-Gaur, R.; Salzwedel, K.; Kilgore, N. R.; Reddick, M.; Matallana, C.; Castillo, A.; Zoumplis, D.; Martin, D. E.; Orenstein, J. M.; Allaway, G. P.; Freed, E. O.; Wild, C. T.; Proc. Natl. Acad. Sci. U. S. A. 2003, 100, 13555.

64. Chandramu, C.; Manohar, R. D.; Krupadanam, D. G.; Dashavantha, R. V.; Phytother. Res. 2003, 27, 129.

65. Bringmann, G.; Saeb, W.; Assi, L. A.; Francois, G.; Narayanan, A. S. S.; Peters, K.; Petera, E. M.; Planta Med. 2007, 63, 255.

66. Cichewicz, R. H.; Kouzi, S. A.; Med. Res. Rev. 2004, 24, 90.

67. Meng, F.; Ning, H.; Sun, Z.; Huang, F.; Li, Y.; Chu, X.; Lu, H.; Sun, C.; Li, S.; J. Funct. Foods 2015, 17, 172.

68. Ikeda, Y.; Murakami, A.; Ohigashi, H.; Mol. Nutr. Food Res. 2008, 52, 26.

69. Fontanay, S.; Grare, M.; Mayer, J.; Finance, C.; Duval, R. E.; J. Ethnopharmacol. 2008, 120, 272.

70. Checker, R.; Sandur, S. K.; Sharma, D.; Patwardhan, R. S.; Jayakumar, S.; Kohli, V.; Sethi, G.; Aggarwal, B. B.; Sainis, K. B.; PLoS One 2012, 7, 313.

71. Yin, M. C.; Chan, K. C.; J. Agric. Food. Chem. 2007, 55, 7177.

72. Fai, Y. M.; Tao, C. C.; Nat. Prod. Med. 2009, $2,77$.

73. Pollier, J.; Goossens, A.; Phytochemistry 2012, 77, 10.

74. Gao, D.; Li, Q.; Li, Y.; Liu, Z.; Fan, Y.; Liu, Z.; Zhao, H.; Li, J.; Han, Z.; Phytother. Res. 2009, 23, 1257. 
75. Liu, J.; J. Ethnopharmacol. 1995, 49, 57.

76. Jimenez-Arellanes, A. J.; Luna-Herrera, J.; Cornejo-Garrido, J.; Lopez-García, S. L.; Castro-Mussot, M. E.; Meckes-Fischer, M.; Mata-Espinoza, D.; Marquina, B.; Torres, J.; Pando, R. H.; BMC Complementary Altern. Med. 2013, 13, 258.

77. Ridhay, A.; Noor, A.; Soekamto, N. H.; Harlim, T.; van Altena, I.; Indones. J. Chem. 2012, 12, 100.

78. Prinsen, P.; Gutierrez, A.; del Rio, J. C.; J. Agric. Food Chem. 2012, 60, 6408 .

79. Windhaus, A.; Hauth, A.; Ber. Dtsch. Chem. Ges. 1907, 39, 4378.

80. Fitches, H. J. M.; Adv. Mass Spectrom. 1963, 428, 55.

81. Mohammed, M. S.; Ahmed, W. J.; Khalid, H. S.; Mahmoud, A. M.; Garelnabi, E. A. E.; Int. J. Pharm. Chem. Biol. Sci. 2014, $4,453$.

82. Correa, G. M.; Abreu, V. G. C.; Martins, D. A. A.; Takahashi, J. A.; Fontoura, H. S.; Cara, D. C.; Pilo-Veloso, D.; Alcantara, A. F. C.; Int. J. Pharm. Pharm. Sci. 2014, 6, 75.

83. Lu, B.; Zhou, F.; Yang, J.; Hu, Y.; Mao, S.; Jiang, Y.; Hong, Y.; Patent No. CN 1038453432014.

84. Githinji, C. G.; Mbugua, P. M.; Kanui, T. I.; Kariuki, D. K.; Phytopharmacology 2012, 2, 212.

85. Chung, I. M.; Kong, W. S.; Lee, O. K.; Park, J. S.; Ahmad, A.; Food Sci. Biotechnol. 2005, 14, 255.

86. Vahouny, G. V.; Connor, W. E.; Subramaniam, S.; Lin, D. S.; Gallo, L. L.; Am. J. Clin. Nutr. 1983, 37, 805.

87. Ikeda, I.; Tanaka, K.; Sugano, M.; Vahouny, G. V.; Gallo, L. L.; J. Lipid Res. 1988, 29, 121573.

88. Sriraman, S.; Ramanujam, G. M.; Ramasamy, M.; Dubey, G. P.; J. Pharm. Biomed. Anal. 2015, 115, 55.

89. Parlapally, S.; Cherukupalli, N.; Bhumireddy, S. R.; Sripadi, P.; Anisetti, R.; Giri, C. C.; Khareedu, V. R.; Reddy, V. D.; Nat. Prod. Res. 2015, $8,1$.

90. Ibraheim, Z. Z.; Ahmed, A. S.; Abdel-Mageed, W. M.; J. Nat. Rem. 2013, 13, 35.

91. Jos, A.; Bhobe, M.; Pednekar, A.; Am. J. Pharm. Health Res. 2013, $1,27$.

92. Lee, Y. S.; Kang, O. H.; Choi, J. G.; Oh, Y. C.; Keum, J. H.; Kim, S. B.; Jeong, G. S.; Kim, Y. C.; Shin, D. W.; Kwon, D. Y.; Pharm. Biol. 2010, 48, 1285.

93. Loizou, S.; Lekakis, I.; Chrousos, G. P.; Moutsatsou, P.; Mol. Nutr. Food Res. 2010, 54, 4551.

94. Nirmal, S. A.; Pal, S. C.; Mandal, S. C.; Patil, A. N.; Inflammopharmacology 2012, 20, 219.

95. Klippel, K. F.; Hiltl, D. M.; Schipp, B.; Br. J. Urol. 1997, 80, 427.

96. Rauf, A.; Uddin, G.; Khanb, H.; Raza, M.; Zafar, M.; Tokuda, H.; Nat. Prod. Res. 2016, 30, 1205.
97. Mallaiah, K. V.; Kumar, A.; Sarma, P. N.; Srimannarayana, G.; Curr. Sci. 1984, 53, 33.

98. Ashok, D.; Sarma, P. N.; Indian J. Chem., Sect. B: Org. Chem. Incl. Med. Chem. 1988, 27B, 862.

99. Agarwal, S. K.; Singh, S. S.; Verma, S.; Kumar, S.; J. Ethnopharmacol. 2000, 72, 43.

100. Wijesekara, I.; Zhang, C.; Van Ta, Q.; Vo, T. S.; Li, Y. X.; Kim, S. K.; Microbiol. Res. 2014, 169, 255.

101. Huang, Q.; Lu, G.; Shen, H. M.; Chung, M. C.; Ong, C. N.; Med. Res. Rev. 2007, 27, 609.

102. Arosio, B.; Gagliano, N.; Fusaro, L. M.; Parmeggiani, L.; Tagliabue, J.; Galetti, P.; Pharmacol. Toxicol. 2000, 87, 229.

103. Fosse, C.; Le Texier, L.; Roy, S.; Delaforge, M.; Grégoire, S.; Neuwels, M.; Azerad, R.; Appl. Microbiol. Biotechnol. 2004, $65,446$.

104. Lin, S. Z.; Chen, K. J.; Tong, H. F.; Jing, H.; Li, H.; Zheng, S. S.; Clin. Exp. Pharmacol. Physiol. 2010, 37, 790.

105. Meng, G.; Liu, Y.; Lou, C.; Yang, H.; Br. J. Pharmacol. 2010, 161,1628

106. Heo, S. K.; Yun, H. J.; Park, W. H.; Park, S. D.; J. Cell. Biochem. 2008, 105, 70.

107. Alves, D. S.; Pérez-Fons, L.; Estepa, A.; Micol, V.; Biochem. Pharmacol. 2004, 68, 549.

108. Srinivas, G.; Babykutty, S.; Sathiadevan, P. P.; Srinivas, P.; Med. Res. Rev. 2007, 27, 591.

109. Lu, Y.; Yang, J. H.; Li, X.; Hwangbo, K.; Hwang, S. L.; Taketomi, Y.; Murakami, M.; Chang, Y. C.; Kim, C. H.; Son, J. K.; Chang, H. W.; Biochem. Pharmacol. 2011, 82, 1700.

110. Tai, M.; Zhang, J.; Song, S.; Miao, R.; Liu, S.; Pang, Q.; Wu, Q.; Liu, C.; Int. Immunopharmacol. 2015, 27, 164.

111. Balyan, R.; Kudugunti, S. K.; Hamad, H. A.; Yousef, M. S.; Moridani, M. Y.; Chem.-Biol. Interact. 2015, 240, 208.

112. Singh, M.; Singh, J.; Z. Naturforsch. 1985, 40b, 550.

113. Sinha, K. S.; Sinha, S. K.; Dwivedi, N.; J. Indian Chem. Soc. 1985, 62, 169.

114. Singh, M.; Singh, J.; Z. Naturforsch. 1984, 39b, 1425.

115. Lin, L.; Majella, E. L.; J. Pharm. 2015, 490, 155.

116. Herman, A.; Herman, A. P.; Skin Pharmacol. Physiol. 2012, 8 , 14.

117. Tsai, C. M.; Sun, F. M.; Chen, Y. L.; Hsu, C. L.; Yen, G. C.; Weng, C. J.; Eur. J. Pharm. Sci. 2013, 48, 494.

118. Viegas Jr., C.; Rezende, A.; Silva, D. H. S.; Castro-Gamboa, I.; Bolzani, V. S. Quim. Nova 2006, 29, 1279.

Submitted: September 15, 2016 Published online: December 15, 2016 